\title{
A REVIEW OF PLANTS USED AGAINST DIABETES MELLITUS BY BAPEDI AND VHAVENDA ETHNIC GROUPS IN THE LIMPOPO PROVINCE, SOUTH AFRICA
}

\author{
SEMENYA SEBUA SILAS ${ }^{1}$, MAROYI ALFRED ${ }^{2}$
}

${ }^{1}$ Department of Research Administration and Development, University of Limpopo, Sovenga, South Africa. ${ }^{2}$ Department of Botany, Medicinal Plants and Economic Development Research Centre, University of Fort Hare, Alice, South Africa. Email: amaroyi@ufh.ac.za

Received: 18 July 2019, Revised and Accepted: 20 August 2019

\section{ABSTRACT}

Traditional utilization of medicinal plants against diabetes mellitus (DM) is common in South Africa and other African countries. This study was aimed at documenting medicinal plants used against DM by the Bapedi and Vhavenda ethnic groups of the Limpopo province, South Africa. This study was based on a review of literature published in scientific journals, books, reports from national, regional, and international organizations, theses and conference papers obtained from libraries and electronic databases. A total of 61 plant species belonging to 39 botanical families, mainly the Fabaceae $(\mathrm{n}=6)$, Asteraceae $(\mathrm{n}=5)$, and Cucurbitaceae $(\mathrm{n}=4)$ were used by Bapedi $(\mathrm{n}=33)$ and Vhavenda $(\mathrm{n}=25)$ to treat and manage DM. Cassia abbreviata, Momordica balsamina, and Moringa oleifera are used by both the Bapedi and Vhavenda people. Plant parts widely used to prepare DM medicines include roots $(40.0 \%)$, leaves $(27.0 \%)$, bark (15.0\%), and whole plant (7.0\%). Monotherapy preparations made from a single plant species are the most dominant (88.5\%) while $11.5 \%$ are prepared from a combination of two or more species. More than half (65.5\%) of the species used to treat and manage DM are known to possess antidiabetic activities and various secondary metabolites. This study illustrates the importance of medicinal plants in the treatment and management of DM in South Africa.

Keywords: Diabetes mellitus, Ethnopharmacology, Medicinal plants, Limpopo Province, South Africa.

(C) 2019 The Authors. Published by Innovare Academic Sciences Pvt Ltd. This is an open access article under the CC BY license (http://creativecommons. org/licenses/by/4. 0/) DOI: http://dx.doi.org/10.22159/ajpcr.2019.v12i10.34993

\section{INTRODUCTION}

Diabetes mellitus (DM) is a major cause of morbidity and mortality worldwide that occurs either when the pancreas does not produce enough insulin (a hormone that regulates blood sugar, or glucose), or when the body cannot effectively use the insulin it produces [1]. In 2006, about 230 million people, representing $6 \%$ of the world population were diagnosed with this disease, of which $80 \%$ were from the developing world [2]. According to the World Health Organization [1], diabetes caused 1.5 million deaths in 2012, with more mortality reported in low- and middle-income countries than in high-income countries. DM is a public health challenge in Africa, where $7,146,000$ people were diagnosed with the diseases in 2000, with a projected increase to $18,645,000$ in 2030 [3]. An estimated 1.5 million deaths were reported in 2012 among Africans, directly caused by this chronic disease of lifestyle [4]. About 3.9 million Nigerians are diabetic [5], over $60 \%$ of Kenyan population is diabetic [6], while $5.7 \%$ of Zimbabwean population is diabetic [7]. DM is also widespread among the Egyptian population aged between 10 and 79 years, with nearly $10.4 \%$ DM incidence [8]. RSesearch by Thinyane and Theketsa [9] showed that 31,000 people in Lesotho are diabetic and the number is expected to increase to 42,000 by 2030 . DM is also one of the major non-communicable diseases in South Africa, considered to be ninth among the top ten leading causes of premature mortality in the country [10]. Recent data from International Diabetes Federation [11] found that 7\% (translating to about 3.85 million) of South Africans between the ages of 21 and 79 years have DM.

DM of all types can lead to serious complications including heart attack, stroke, kidney failure, leg amputation, vision loss, and nerve damage, thus increasing the overall risk of dying prematurely [4]. The cornerstones of diabetes management and treatment include lifestyle intervention (that is, healthy diet and physical activity) along with pharmacological therapy and routine blood glucose monitoring [12]. Common pharmacological agents such as bile acid sequestrant, dipeptidyl peptidase IV, dopamine agonist, meglitinides, metformin, sodium-glucose transport protein inhibitors, sulfonylureas, thiazolidinediones, and $\alpha$-glucosidase inhibitors are available to manage complications of DM by lowering blood glucose [13]. In most developing countries, the majority of people rely on traditional healers' services and medicinal plants to treat and manage DM. This is highlighted by number of studies focusing on this ailment in several countries including Nigeria [14], Uganda [15], Kenya [16], Algeria [17], Cameroon [18], Morocco [19], and South Africa [20-23]. The Limpopo Province in South Africa is inhabited by diverse ethnic groups [24] such as Bapedi (52.94\%), Vhatsonga (16.98\%), and Vhavenda (16.72\%). The present study was aimed at documenting medicinal plants used against DM by the Bapedi and Vhavenda ethnic groups of the Limpopo Province, South Africa.

\section{FOLKLORE MEDICINAL PLANTS USED TO TREAT DM IN THE LIMPOPO PROVINCE}

The present review study recorded 61 plant species from 39 botanical families, mainly the Fabaceae $(\mathrm{n}=6)$, Asteraceae $(\mathrm{n}=5)$, Cucurbitaceae $(\mathrm{n}=4)$, and Asphodelaceae and Tiliaceae $(\mathrm{n}=3)$ that are used by the Bapedi and Vhavenda ethnic groups of the Limpopo Province, South Africa to treat and manage DM (Table 1). The majority of the species $(n=33)$ are used by the Bapedi ethnic group, while 25 species are used by the Vhavenda. This indicates that there is very little overlap in terms of information on herbal medicines for DM among the Vhavenda and Bapedi people. The medicinal plant used by both Bapedi and Vhavenda includes Cassia abbreviata, Momordica balsamina, and Moringa oleifera. Comparison between finding of this study and literature reporting on the use of medicinal plants for DM by other cultures in South Africa and elsewhere showed that Aloe arborescens, Aloe marlothii, Anthocleista grandiflora, Callilepis laureola, Cannabis sativa, Carica papaya, Carpobrotus edulis, C. abbreviata, Catharanthus roseus, Centella asiatica, Citrus limon, Combretum molle, Cucurbita pepo, Cymbopogon citratus, Elaeodendron transvaalense, Euclea natalensis, Ficus carica, Ficus sycomorus, Grewia villosa, Hypoxis hemerocallidea, Mangifera indica, M. oleifera, M. balsamina, M. charantia, M. foetida, 
Table 1: Plants used traditionally to treat diabetes mellitus in the Limpopo Province, South Africa

\begin{tabular}{|c|c|c|c|c|c|}
\hline Family & Scientific name & $\begin{array}{l}\text { Vernacular name V (Venda), } \\
\text { S (Sepedi), and T (Tsonga) }\end{array}$ & Habit & Parts used & $\begin{array}{l}\text { Antidiabetic } \\
\text { activity }\end{array}$ \\
\hline Acanthaceae & "Blepharis spp Juss & Bohlobohlo (S) & Shrub & Roots [26] & - \\
\hline Aizoaceae & "Carpobrotus edulis (L.) L. Bol. & Lepolomo la go naba/moshipse (S) & Herb & Leaves [22] & [27] \\
\hline Anacardiaceae & ${ }^{€}$ Mangifera indica Wall. & Munngo (V) & Tree & Bark [28] & [29] \\
\hline Anacardiaceae & Searsia lancea (L.f.) F. A. Barkley & Mushakaladza (V) & Tree & Macerated in water [30] & - \\
\hline Amaranthaceae & "Gomphrena celosioides Mart. & Lebolomo la naga (S) & Herb & Roots [26] & - \\
\hline Amaryllidaceae & $\begin{array}{l}\text { "Gethyllis namaquensis } \\
\text { (Schonland) Oberm. }\end{array}$ & Naka tsa tholo $(\mathrm{S})$ & Herb & Bulb [22] & - \\
\hline Apiaceae & ${ }^{\# C e n t e l l a ~ a s i a t i c a ~(L .) ~ U r b . ~}$ & Unknown & Herb & Roots [22] & [31] \\
\hline Apocynaceae & ${ }^{€}$ Catharanthus roseus (L.) G. Don & Luvha (V) & Herb & Roots [28] & [32] \\
\hline Apocynaceae & "Plumeria obtusa L. & Mohlare wa maswi wa sukiri (S) & Tree & Leaves [22] & - \\
\hline Araliaceae & "Cussinia spicata Thunb. & Unknown & Herb & Roots [22] & - \\
\hline Asparagaceae & $\begin{array}{l}\text { "Sansevieria hyacinthoides (L.) } \\
\text { Druce. }\end{array}$ & Mokgotla (S) & Shrub & Roots [26] & - \\
\hline Asphodelaceae & ${ }^{€}$ Aloe arborescens Mill. & Tshikhopha (V) & Shrub & Leaves [28] & [37] \\
\hline Asphodelaceae & $\begin{array}{l}\text { "Aloe marlothii A. Berger subsp. } \\
\text { Marlothii }\end{array}$ & Kgopha ya go eema (S) & Tree & Leaves [22] & - \\
\hline Asphodelaceae & Aloe micracantha Haw & Tshikhopha tshituku (V) & Tree & Leaves [30] & - \\
\hline Asteraceae & $\begin{array}{l}\text { "Helichrysum caespititium (DC) } \\
\text { Harv. }\end{array}$ & Bokgatha/Mabjana/Mmeetse (S) & Herb & Whole plant [22] & - \\
\hline Asteraceae & "Callilepis laureola DC. & Phela & Herb & Roots [22] & - \\
\hline Asteraceae & ${ }^{€}$ Schkuhria pinnata (Lam.) Kuntze & Luswielo (V) & Herb & Whole plant $[28,33]$ & [34] \\
\hline Asteraceae & ${ }^{€}$ Vernonia colorata Drake & Phathane (V) & Shrub & Leaves [28] & [35] \\
\hline Asteraceae & "Tarchonanthus camphoratus L. & Moologa (S) & Tree & Roots [22] & [36] \\
\hline Cactaceae & "Opuntia ficus-indica Mill & Motloro/Torofeiye (S) & Tree & $\begin{array}{l}\text { Leaves or roots [22,38], } \\
\text { leaves mixed with Momordica } \\
\text { balsamina and Aloe spp. [26] }\end{array}$ & [39] \\
\hline Canellaceae & $\begin{array}{l}{ }^{€} \text { Warburgia salutaris (G. Bertol.) } \\
\text { Chiov. }\end{array}$ & Mulanga (V) & Tree & Bark [28] & {$[40]$} \\
\hline Cannabaceae & ${ }^{€}$ Cannabis sativa $\mathrm{L}$. & Mbanzhe (V) & Herb & Whole plant [28] & [41] \\
\hline Caricaceae & ${ }^{\#}$ Carica papaya L. & Mophopho (S) & Tree & Roots [22] & [42] \\
\hline Celastraceae & $\begin{array}{l}{ }^{E} \text { Elaeodendron } \\
\text { transvaalense (Burtt Davy) R. H. } \\
\text { Archer }\end{array}$ & Mukuvhazwivhi (V) & Tree & Bark [28] & $\begin{array}{l}\text { Deutschländer } \\
(2010)\end{array}$ \\
\hline Combretaceae & Combretum molle R. Br. ex G. Do & Mugwiti (V) & Tree & Leaves [30] & [43] \\
\hline Cucurbitaceae & 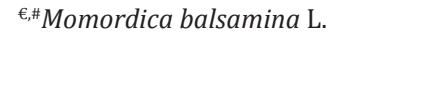 & $\begin{array}{l}\text { Lugu (V), Nkgakga, nku, } \\
\text { Mothwatwa (S) }\end{array}$ & Herb & $\begin{array}{l}\text { Leaves }[22,28], \text { leaves } \\
\text { mixed with Aloe spp. and } \\
\text { Opuntia ficus-indica [26] }\end{array}$ & [44] \\
\hline Cucurbitaceae & "Momordica charantia L. & Monamelala (S) & Herb & Leaves [22] & {$[45,46]$} \\
\hline Cucurbitaceae & Momordica foetida Schumach & Nngu (V) & Herb & Leaves [30] & [47] \\
\hline Cucurbitaceae & Cucurbita pepo L. & Thanga (V) & Herb & Fruits [30] & [48] \\
\hline Ebenaceae & $\begin{array}{l}{ }^{\#} \text { Euclea natalensis A.DC subsp. } \\
\text { angustifolia F White }\end{array}$ & Mohlakola (S) & Tree & Roots [26] & {$[40]$} \\
\hline Euphorbiaceae & Bridelia mollis Hutch & Mukumba kumba (V) & Tree & Leaves [30] & - \\
\hline Fabaceae & €,\#Cassia abbreviata $\mathrm{L}$. & $\begin{array}{l}\text { Munembenembe (V), } \\
\text { Molomanama (S) }\end{array}$ & Tree & $\begin{array}{l}\text { Bark or roots }[26,28,49,50] \text {, } \\
\text { bark mixed with Ficus } \\
\text { sycomorus and Grewia } \\
\text { occidentalis }[28]\end{array}$ & [49] \\
\hline Fabaceae & ${ }^{€}$ Elephantorrhiza burkei Benth. & Gumululo (V) & Tree & Bark [28] & - \\
\hline Fabaceae & 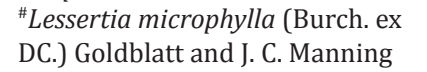 & Mosapelo (S) & Shrub & Roots [22] & [51] \\
\hline Fabaceae & ${ }^{E}$ Schotia brachypetala Sond. & Mulubi (V) & Tree & Roots [28] & - \\
\hline Fabaceae & ${ }^{\#}$ Senna italica Mill. & Setlommana (S) & Shrub & Roots $[26,49]$ & [49] \\
\hline Fabaceae & Senna petersiana (Bolle) Lock & Munembenembe (V) & Tree & Fruits or roots [30] & - \\
\hline Hypoxidaceae & $\begin{array}{l}{ }^{€} \text { Hypoxis hemerocallidea Fisch., C. } \\
\text { A. Mey and Avé-Lall. }\end{array}$ & Thithigwane (V) & Herb & $\begin{array}{l}\text { Bulb mixed with Citrus } \\
\text { limon [28] }\end{array}$ & {$[52,53]$} \\
\hline Hypoxidaceae & "Hypoxis iridifolia Baker & Monna maledu (S) & Herb & Tuber [22] & - \\
\hline Kirkiaceae & "Kirkia wilmsii Engl. & Legaba/Modumela (S) & Tree & Tuber [22] & - \\
\hline Loganiaceae & ${ }^{€}$ Anthocleista grandiflora Gilg & Mueneene (V) & Tree & Bark [54] & - \\
\hline Lauraceae & "Persea americana Mill. & Moafokhathe (S) & Tree & Roots [22] & [55] \\
\hline Malvaceae & \#Grewia flavescens Juss. & Mpharatshwene (S) & Shrub & Roots [26] & [56] \\
\hline Malvaceae & ${ }^{\#}$ Waltheria indica $L$. & Motayabannyana (S) & Herb & Roots $[26,49]$ & [57] \\
\hline Moraceae & ${ }^{€}$ Ficus sycomorus $\mathrm{L}$. & Muhuyumagalangafhasi (V) & Tree & $\begin{array}{l}\text { Bark mixed with } \\
\text { Cassia abbreviata and } \\
\text { Grewia occidentalis [28] }\end{array}$ & [58] \\
\hline Moraceae & $\begin{array}{l}{ }^{\#} \text { Ficus carica L. subsp. } \\
\text { rupestris (Hausskn.) Browicz }\end{array}$ & Mofeiye (S) & Tree & Roots [22] & [59] \\
\hline Menispermaceae & $\begin{array}{l}\text { "Tinospora fragosa (I. Verd.) I. } \\
\text { Verd. and Troupin }\end{array}$ & Makgonatsohle (S) & Tree & Bark or leaves $[26,49]$ & [49] \\
\hline
\end{tabular}


Table 1: (Continued)

\begin{tabular}{|c|c|c|c|c|c|}
\hline Family & Scientific name & $\begin{array}{l}\text { Vernacular name V (Venda), } \\
\text { S (Sepedi), and T (Tsonga) }\end{array}$ & Habit & Parts used & $\begin{array}{l}\text { Antidiabetic } \\
\text { activity }\end{array}$ \\
\hline Moringaceae & €,\#Moringa oleifera Lam. & Muringa (V); Makgonatsohle (S) & Tree & $\begin{array}{l}\text { Leaves [28], leaves or } \\
\text { seeds [22] }\end{array}$ & [60] \\
\hline Myrtaceae & Psidium guajava Linn & Mugwavha (V) & Tree & Leaves [30] & [61] \\
\hline Poaceae & ${ }^{€}$ Cymbopogon citratus Stapf. & Tie-ya- thavha (V) & Herb & $\begin{array}{l}\text { Whole plant mixed with } \\
\text { Hypoxis hemerocallidea [28] }\end{array}$ & [62] \\
\hline Punicaceae & "Punica granatum L. & Mokgarenate (S) & Tree & Roots [22] & [63] \\
\hline Rhamnaceae & \#Ziziphus mucronata Willd. & Mokgalo (S) & Tree & Roots [26] & [64] \\
\hline Rosaceae & Prunus persica (Linnaeus) Batsch & Muberegisi (V) & Tree & Leaves [30] & [65] \\
\hline Rutaceae & ${ }^{€}$ Citrus limon (L.) Burm.f. & Tshikara (V) & Tree & Fruit [28] & [66] \\
\hline Scrophulariacae & $\begin{array}{l}{ }^{\#} \text { Aptosium linearize Marloth and } \\
\text { Engl. }\end{array}$ & Unknown & Herb & Roots [26] & - \\
\hline Sapotaceae & ${ }^{\#}$ Mimusops zeyheri Sond. & Mmupudu (S) & Tree & Leaves [22] & - \\
\hline Sapotaceae & $\begin{array}{l}\text { "Englerophytum } \\
\text { magalismontanum (Sond.) T. D. } \\
\text { Penn. }\end{array}$ & Mohlastwa (S) & Tree & Bark [22] & - \\
\hline Sterculiaceae & "Hermannia quartiniana A. Rich. & Unknown & Herb & Roots [22] & - \\
\hline Tiliaceae & ${ }^{€}$ Grewia occidentalis L. & Mulembu (V) & Tree & $\begin{array}{l}\text { Bark mixed with } \\
\text { Cassia abbreviata and } \\
\text { Ficus sycomorus [28] }\end{array}$ & - \\
\hline Tiliaceae & ${ }^{\#}$ Grewia villosa Willd & Mopharantshone (S) & Shrub & Roots [26] & - \\
\hline Tiliaceae & ${ }^{\#}$ Triumfetta spp. & Unknown & Herb & Roots [22] & - \\
\hline
\end{tabular}

Vernacular name: $\mathrm{S}=$ Sepedi, V=Tshivenda; Bapedi (\#), Vhavenda (€) and VhaTsonga ( $\neq$ )

Opuntia ficus-indica, Persea americana, Prunus persica, Psidium guajava, Punica granatum, Schkuhria pinnata, Senna italica, Tarchonanthus camphoratus, Vernonia colorata, Waltheria indica, Warburgia salutaris, and Ziziphus mucronata are popular as DM remedies (Table 2). Some of these species particularly, C. papaya, C. citratus, F. carica, F. sycomorus, G. villosa, M. indica, M. oleifera, M. charantia, O. ficus-indica, P. americana, P. persica, P. granatum, S. italica, and Z. mucronata are well-known edible food plants in South Africa and other countries. Therefore, their oral prescription as DM therapies might be safe, and future research should thus, focus on evaluating their nutraceutical, and/or functional properties. The traditional knowledge of the therapeutic utilization of the rest of the species, namely, Aloe micracantha, Aptosium linearize, Bridelia mollis, Cussonia spicata, Elephantorrhiza burkei, Englerophytum magalismontanum, Gethyllis namaquensis, Gomphrena celosioides, Grewia flavescens, Grewia occidentalis, Helichrysum caespititium, Hermannia quartiniana, Hypoxis iridifolia, Kirkia wilmsii, Lessertia microphylla, Mimusops zeyheri, Plumeria obtusa, Schotia brachypetala, Searsia lancea, Senna petersiana, and Tinospora fragosa as DM remedies is presently restricted to either the Bapedi or Vhavenda people of the Limpopo Province, South Africa. This finding corroborates the observation made by Watson and Preedy [25] that each ethnic culture has its own relationship with the environment and a medical knowledge that uses specific therapeutic plants.

\section{PLANT HABIT AND PARTS USED}

Trees $(52.5 \%)$, herbs $(34.4 \%)$, and shrubs $(13.1 \%)$ are the primary sources of medicinal plants used to treat and manage DM in the Limpopo Province (Table 1$)$ were tree $(n=32)$, herbs $(n=21)$, and shrubs $(\mathrm{n}=8)$. In research studies carried by Amal and Masarrat [97] and Nasution et al. [98], trees and herbs were reported as primary sources of medicinal plants against this disease. Trees are known to be nonseasonal in nature which implies that they are accessible throughout a year; hence, their parts are preferred by indigenous people for remedy preparations in the Limpopo Province. Likewise, herbs are usually abundant and are easy to collect. Plant parts widely used to prepare DM medicines include roots (40.0\%), leaves (27.0\%), bark (15.0\%), and whole plant (7.0\%) (Fig. 1). Similar findings were reported among other indigenous people in South Africa [20], Kenya [16], and Republic of Benin [99]. Monotherapy preparations made from a single plant species are the most dominant (88.5\%) while $11.5 \%$ are prepared from a combination of two or more species. Similar findings were reported

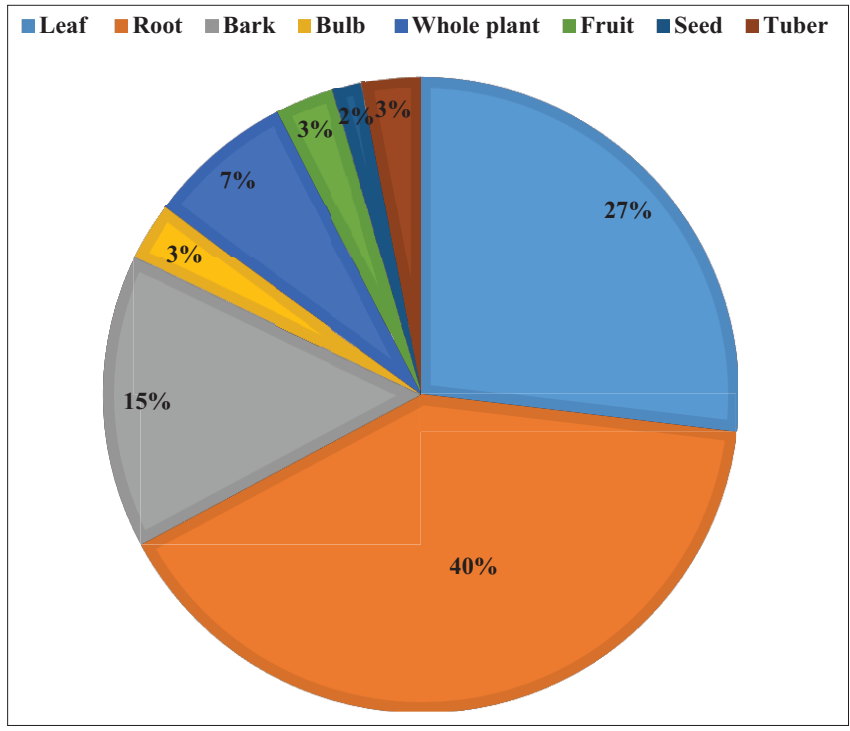

Fig. 1: Plant parts used to treat diabetes mellitus in the Limpopo Province, South Africa

by various authors focusing on DM in other countries of the world such as Bangladesh [100], India [101], and Malaysia [102]. Contrary to the findings of the current study, indigenous people residing in Nigeria [103,104] and Kenya [16] mainly prepare DM herbal recipes from a combination of parts obtained from different plants. Bussmann and Sharon [105] and Rasoanaivo et al. [106] argued that mixing dissimilar plant species during medicinal preparation is done to augment the efficacy of the herbal medicines. Therefore, preference of mono recipes among the Bapedi and Vhavenda people may imply that the used medicinal plant species contain potent phytochemicals that are effective against DM.

\section{ANTIDIABETIC ACTIVITIES OF USED MEDICINAL PLANTS}

A review of the scientific literature reporting on antidiabetic activity of the 61 medicinal plant species used by Bapedi and Vhavenda people of the Limpopo Province to treat and manage DM was conducted. The results showed that 40 species $(65.6 \%)$ have antidiabetic properties 
Table 2: Plants used to treat diabetes mellitus in other areas of South Africa and elsewhere

\begin{tabular}{|c|c|}
\hline Species & Country of utilization \\
\hline Aloe arborescens & South Africa $[67,68]$ \\
\hline Aloe marlothii & South Africa [69] \\
\hline Aloe micracantha & None found \\
\hline Anthocleista grandiflora & South Africa [70] \\
\hline Aptosium linearize & None found \\
\hline Bridelia mollis & None found \\
\hline Blepharis spp. & None found \\
\hline Callilepis laureola & South Africa [67] \\
\hline Cannabis sativa & South Africa [67] \\
\hline \multirow[t]{2}{*}{ Carica papaya } & Nigeria[71] and \\
\hline & Zambia [72] \\
\hline Carpobrotus edulis & South Africa $[73,74]$ \\
\hline Cassia abbreviate & Kenya [75] \\
\hline Catharanthus roseus & $\begin{array}{l}\text { South Africa }[20,67] \text { and } \\
\text { Jordan }[76]\end{array}$ \\
\hline Centella asiatica & India [77] \\
\hline Citrus limon & India [78] \\
\hline Combretum molle & Tanzania [79] \\
\hline Cussonia spicata & None found \\
\hline Cucurbita pepo & South Africa [80] \\
\hline Cymbopogon citratus & Trinidad and Tobago [81] \\
\hline Elaeodendron transvaalense & South Africa [34] \\
\hline Elephantorrhiza burkei & None found \\
\hline Englerophytum magalismontanum & None found \\
\hline Euclea natalensis & South Africa [34] \\
\hline Ficus carica & Pakistan [82] \\
\hline Ficus sycomorus & Nigeria [83] \\
\hline Gethyllis namaquensis & None found \\
\hline Gomphrena celosioides & None found \\
\hline Grewia flavescens & None found \\
\hline Grewia occidentalis & None found \\
\hline Grewia villosa & Pakistan [84] \\
\hline Helichrysum caespititium & None found \\
\hline Hermannia quartiniana & None found \\
\hline Hypoxis hemerocallidea & South Africa [23] \\
\hline Hypoxis iridifolia & None found \\
\hline Kirkia wilmsii & None found \\
\hline Lessertia microphylla & None found \\
\hline Mangifera indica & Guinea[85] and Nigeria [86] \\
\hline Mimusops zeyheri & None found \\
\hline Momordica balsamina & South Africa [23,87] \\
\hline Momordica foetida & South Africa [23] \\
\hline Moringa oleifera & India $[88]$ \\
\hline Momordica charantia & Trinidad and Tobago [89] \\
\hline Opuntia ficus-indica & Jordan $[90]$ \\
\hline Persea Americana & Mauritius [76] \\
\hline Plumeria obtuse & None found \\
\hline Psidium guajava & South Africa [23] \\
\hline Prunus persica & Brazil [91] \\
\hline Punica granatum & Tunisia [92] \\
\hline Sansevieria hyacinthoides & None found \\
\hline Senna petersiana & None found \\
\hline Searsia lancea & None found \\
\hline Schkuhria pinnata & South Africa [93] \\
\hline Schotia brachypetala & None found \\
\hline Senna italic & India [94] \\
\hline Tarchonanthus camphoratus & South Africa [23] \\
\hline Tinospora fragosa & None found \\
\hline Triumfetta spp. & None found \\
\hline Vernonia colorata & Côte-d'Ivoire [95] \\
\hline Waltheria indica & India [57] \\
\hline Warburgia salutaris & South Africa [34] \\
\hline Ziziphus mucronata & Congo [96] \\
\hline
\end{tabular}

(Table 1), thus providing support to their traditional usage as a remedy for DM by these cultures. For instance, the oral administration of C. roseus leaf powder produces an antihyperglycemic effect, and lowed both total cholesterol and triglyceride levels, while increasing HDLcholesterol in STZ-induced diabetic rats [32]. Flavonoids compounds including quercetin isolated from $C$. реро encompass hypoglycemic effect in diabetic rats [48]. Chauhan [59] found that the F carica (200 mg/kg p.o) methanolic extract which was orally dispensed to diabetic rats, reduced blood glucose levels and triglycerides after observation. Extracts (aqueous) from another Ficus species; F. sycomorus was assessed by Njagi et al. [58] for antidiabetic potential and also evaluated for in vivo toxicity in alloxan-induced diabetic mice. The results indicated that $F$. sycomorus contains antidiabetic activity and it safely lowered blood glucose level to levels way below what insulin, the model drug, lowers, in a dose-dependent manner. Similarly, extract (50-800 mg/kg) of $H$. hemerocallidea significantly reduced hypoglycemia in both normal (normoglycemic) and diabetic rats [52], therefore, proving to be an alternative remedy for the treatment of DM. Likewise, dosage of $100 \mathrm{mg} / \mathrm{kg}$ and $200 \mathrm{mg} / \mathrm{kg}$ of the $C$. papaya seeds extract significantly decreased blood glucose levels on this rat [42]. The acetone extract of whole fruit powder of Momordica charantia in doses $0.25,0.50$, and $0.75 \mathrm{mg} / \mathrm{kg}$ body weight lowered the blood glucose from $13.3 \%$ to $50.0 \%$ after 8 -30-day treatment in alloxan diabetic albino rats [46]. Overall, outcomes of the afore-mentioned scientific studies suggest that the mentioned plants and those which harbors antidiabetic activity depicted in Table 1, may be of great value in managing DM in human beings, and are also potential candidates for further exploration for possible herbal drugs development $[107,108]$. However, the mechanisms of action against DM of remaining 25 species; 16 used by Bapedi and four by Vhavenda, remain unknown. Therefore, further studies should be conducted to explore the antidiabetic activity and responsible bioactive compounds of these plants, especially A. micracantha, A. linearize, B. mollis, E. magalismontanum, $G$. namaquensis, G. villosa, H. quartiniana, and M. zeyheri which none of their active principles have not yet been evaluated.

\section{CONCLUSION}

The present study revealed that the Bapedi and Vhavenda people in the Limpopo Province still use traditional plant-based medicines to treat and manage DM. Some the species documented in this study are also used elsewhere as therapies for DM and are characterized by antidiabetic activities. Therefore, there are a need for detailed phytochemical, pharmacological, and toxicological evaluations aimed at correlating medicinal uses of such species with their phytochemistry and pharmacological activities.

\section{AUTHORS' CONTRIBUTIONS}

SSS collected data and wrote the draft manuscript, while AM revised the manuscript.

\section{CONFLICTS OF INTEREST}

The author declares that there are no conflicts of interest regarding the publication of this paper.

\section{ACKNOWLEDGMENTS}

The authors would like to express their gratitude to Govan Mbeki Research and Development Centre, University of Fort Hare for financial support to conduct this study.

\section{REFERENCES}

1. World Health Organization. Global Report on Diabetes. Geneva: World Health Organization; 2016.

2. Roglic G, Unwin N, Bennett PH, Mathers C, Tuomilehto J, Nag S, et al. The burden of mortality attributable to diabetes: Realistic estimates for the year 2000. Diabetes Care 2005;28:2130-5.

3. Wild S, Roglic G, Green A, Sicree R, King H. Global prevalence of diabetes: Estimates for the year 2000 and projections for 2030 . Diabetes Care 2004;27:1047-53.

4. World Health Organization. Factsheet: Diabetes. Geneva: World Health Organization, Regional Office for Africa; 2017.

5. Chiwanga FS, Njelekela MA, Diamond MB, Bajunirwe F, Guwatudde D, Nankya-Mutyoba J, et al. Urban and rural prevalence 
of diabetes and pre-diabetes and risk factors associated with diabetes in Tanzania and Uganda. Glob Health Action 2016;9:31440.

6. Ministry of Public Health and Sanitation. Kenya National Diabetes Strategy 2010-2015. Nairobi: Ministry of Public Health and Sanitation; 2010

7. Mutowo M, Gowda U, Mangwiro JC, Lorgelly P, Owen A, Renzaho A, et al. Prevalence of diabetes in Zimbabwe: A systematic review with meta-analysis. Int J Public Health 2015;60:1-1.

8. Ahmed OS. Diabetes mellitus in Egypt in short. J Diabetes Metab 2013;4:10.

9. Thinyane KH, Theketsa CE. Characteristics of patients admitted with diabetes in Maseru, Lesotho. Afr J Diabetes Med 2013;21:17-9.

10. Pillay-van Wyk V, Msemburi W, Laubscher R, Dorrington RE, Groenewald P, Glass T, et al. Mortality trends and differentials in South Africa from 1997 to 2012: Second national burden of disease study. Lancet Glob Health 2016;4:e642-53.

11. International Diabetes Federation. International Diabetes Federation Diabetes Atlas. Brussels: International Diabetes Federation; 2015.

12. Chaudhury A, Duvoor C, Reddy Dendi VS, Kraleti S, Chada A, Ravilla R, et al. Clinical review of antidiabetic drugs: Implications for Type 2 diabetes mellitus management. Front Endocrinol (Lausanne) 2017;8:6.

13. Evans JL, Balkan B, Chuang E, Rushakoff RJ. Oral and injectable (noninsulin) pharmacological agents for Type 2 diabetes. In: de Groot LJ, Chrousos G, Dungan K, Feingold KR, Grossman A, Hershmam JM, et al., editors. Endotext. South Dartmouth: MDText; 2000. p. 23-65.

14. Borokini TI, Ighere DA, Clement M, Ajiboye TO, Alowonle AA. Ethnobiological survey of traditional medicine practice for the treatment of piles and diabetes mellitus in Oyo State. J Med Plants Stud 2013;1:30-40.

15. Rutebemberwa E, Lubega M, Katureebe SK, Oundo A, Kiweewa F, Mukanga D, et al. Use of traditional medicine for the treatment of diabetes in Eastern Uganda: A qualitative exploration of reasons for choice. BMC Int Health Hum Rights 2013;13:1.

16. Keter LK, Mutiso PC. Ethnobotanical studies of medicinal plants used by traditional health practitioners in the management of diabetes in lower Eastern province, Kenya. J Ethnopharmacol 2012;139:74-80.

17. Bouzabata A. Traditional treatment of high blood pressure and diabetes in Souk Ahras district. J Pharmacogn Phytother 2013;5:12-20.

18. Tsabang N, Ngah N, Fokunang TE, Agbor GA. Herbal medicine and treatment of diabetes in Africa: Case study in Cameroon. Diab Case Rep 2016;1:2

19. Laadim M, Ouahidi ML, Zidane L, Ei-Hessni A, Ouichou A, Mesfioui A. Ethnopharmacological survey of plants used for the treatment of diabetes in the town of Sidi Slimane (Morocco). J Pharmacogn Phytother 2017;9:101-10.

20. Erasto P, Adebola P, Grierson D, Afolayan AJ. An ethnobotanical study of plants used for the treatment of diabetes in the Eastern Cape province, South Africa. Afr J Biot 2005;4:1458-60.

21. Boaduo NK. Evaluation of Six Plant Species Used Traditionally in the Treatment and Control of Diabetes Mellitus. MSc Dissertation. Pretoria: University of Pretoria; 2010.

22. Semenya S, Potgieter M, Erasmus L. Ethnobotanical survey of medicinal plants used by bapedi healers to treat diabetes mellitus in the Limpopo province, South Africa. J Ethnopharmacol 2012;141:440-5.

23. Odeyemi S, Bradley G. Medicinal plants used for the traditional management of diabetes in the Eastern Cape, South Africa: Pharmacology and toxicology. Molecules 2018;23:E2759.

24. Statistic South Africa. Statistics by Place. Pretoria: Statistics South Africa; 2015 .

25. Watson RR, Preedy CR. Botanical Medicine in Clinical Practice. London: CABI Publishing; 2008.

26. Chauke MA, Shai LJ, Mogale MA, Tshisikhawe MP, Mokgotho MP. Medicinal plant use of villagers in the Mopani district, Limpopo province, South Africa. Afr J Trad Complement Altern Med 2015;12:9-26.

27. Pringle N, Van de Venter M, Koekemoer T. Antidiabetic Screening of Selected African Natural Products Using an in vitro Targetdirected Screening Platform and Cellomics. Available from: https://www.2018.febscongress.org/abstract_preview. aspx?idAbstractEnc=4424170094091095093094424170. _Last accessed on 2019 Apr 15].

28. Muthaphuli N. Ethnomedicinal Survey of Plant Species Used in the Management of Sugar Diabetes by the Vhavenda People of Muraga Village in Vhembe District. BSc Honours Dissertation. Thohoyandou: University of Venda; 2016.

29. Ganogpichayagrai A, Palanuvej C, Ruangrungsi N. Antidiabetic and anticancer activities of Mangifera indica cv. Okrong leaves. J Adv Pharm Technol Res 2017;8:19-24.

30. Tshidzumba PW. An Inventory and Pharmacological Evaluation of Medicinal Plants Used as Anti-diabetes and Anti-arthritis in Vhembe District Municipality, Limpopo province, South Africa. MSc Dissertation. Thohoyandou: University of Venda; 2005.

31. Emran TB, Dutta M, Uddin MM, Nath AK, Uddin MZ. Antidiabetic potential of the leaf extract of Centella asiatica in alloxaninduced diabetic rats. Jahangirnagar Univ J Biol Sci 2015;4:51-9.

32. Rasineni K, Bellamkonda R, Singareddy SR, Desireddy S. Antihyperglycemic activity of Catharanthus roseus leaf powder in streptozotocin-induced diabetic rats. Pharmacogn Res 2010;2:195-201.

33. Mahwasane ST, Middleton L, Boaduo N. An ethnobotanical survey of indigenous knowledge on medicinal plants used by the traditional healers of the Lwamondo area, Limpopo province, South Africa. S Afr J Bot 2013;88:69-75.

34. Deutschländer MS, Lall N, Van de Venter M. Plant species used in the treatment of diabetes by South African traditional healers: An inventory. Pharm Biol 2009;47:348-65.

35. Sy GY, Cissé A, Nongonierma RB, Sarr M, Mbodj NA, Faye B, et al. Hypoglycaemic and antidiabetic activity of acetonic extract of vernonia colorata leaves in normoglycaemic and alloxan-induced diabetic rats. J Ethnopharmacol 2005;98:171-5.

36. van Huyssteen M, Milne PJ, Campbell EE, van de Venter M. Antidiabetic and cytotoxicity screening of five medicinal plants used by traditional African health practitioners in the nelson mandela metropole, South Africa. Afr J Tradit Complement Altern Med 2011;8:150-8.

37. Beppu H, Shimpo K, Chihara T, Kaneko T, Tamai I, Yamaji S, et al. Antidiabetic effects of dietary administration of Aloe arborescens miller components on multiple low-dose streptozotocin-induced diabetes in mice: Investigation on hypoglycemic action and systemic absorption dynamics of aloe components. J Ethnopharmacol 2006;103:468-77.

38. Maema LP, Potgieter M, Mahlo SM. Invasive alien plant species used for the treatment of various diseases in Limpopo province, South Africa. Afr J Tradit Complement Altern Med 2016;13:223-31.

39. Hwang SH, Kang IJ, Lim SS. Antidiabetic effect of fresh nopal (Opuntia ficus-indica) in low-dose streptozotocin-induced diabetic rats fed a high-fat diet. Evid Based Complement Alternat Med 2017;2017:4380721.

40. Nkobole NK. Antidiabetic Activity of Pentacyclic Triterpenes and Flavonoids Isolated from Stem Bark of Terminalia sericea Burch. ex DC. MSc Dissertation. Pretoria: University of Pretoria; 2009.

41. Tehranipour M, Mahdavi N, Ekrami A. Antidiabetic effect of Cannabis sativa extract in Wister rat. Int J Chem Pharm Res 2012;6:124-30.

42. Venkateshwarlu E, Dileep P, Reddy RR, Sandhya P. Evaluation of antidiabetic activity of Carica papaya seeds on streptozotocin- induced Type ii diabetic rats. J Adv Sci Res 2013;3:38-41.

43. Maroyi A. Combretum molle R.Br. Ex G. Don. In: Schmelzer GH, Gurib-Fakim A, editors. Plant Resources of Tropical Africa 11(2): Medicinal Plants 2. Wageningen: CTA; 2013. p. 78-81.

44. Bhardwaj N, Gauttam V, Kalia AN. Evaluation of antidiabetic activity of Momordica balsamina Linn seeds in experimentally-induced diabetes. J Chem Pharm Res 2010;2:701-7.

45. Shetty AK, Kumar GS, Sambaiah K, Salimath PV. Effect of bitter gourd (Momordica charantia) on glycaemic status in streptozotocin induced diabetic rats. Plant Foods Hum Nutr 2005;60:109-12.

46. Singh N, Gupta M. Regeneration of beta cells in islets of langerhans of pancreas of alloxan diabetic rats by acetone extract of Momordica charantia (Linn.) (bitter gourd) fruits. Indian J Exp Biol 2007; 45:1055-62

47. Osinubi AA, Enye LA, Adesiyun AE, Ajayi GO. Comparative effects of three herbs and standard hypoglycaemic agents on blood glucose in normoglycaemic, hyperglycaemic and alloxan-induced diabetic male rats. Afr J Endocrinol Metab 2008;7:5-9.

48. Rauter AP, Martins A, Borges C, Mota-Filipe H, Pinto R, Sepodes B, et al. Antihyperglycaemic and protective effects of flavonoids on streptozotocin-induced diabetic rats. Phytother Res 2010;24 Suppl 2:S133-8.

49. Shai LJ, Masoko P, Mokgotho MP, Magano SR, Mogale AM, Boaduo N, et al. Yeast alpha glucosidase inhibitory and antioxidant activities of six medicinal plants collected in Phalaborwa, South Africa. S Afr J Bot 2010;76:465-70.

50. Mongalo NI, Makhafola TJ. Ethnobotanical knowledge of the lay people of blouberg area (Pedi tribe), Limpopo province, South Africa. J Ethnobiol Ethnomed 2018;14:46.

51. Aboyade OM, Styger G, Gibson D, Hughes G. Sutherlandia 
frutescens: The meeting of science and traditional knowledge. J Altern Complement Med 2014;20:71-6.

52. Ojewole JA. Antinociceptive, anti-inflammatory and antidiabetic properties of hypoxis hemerocallidea fisch; C.A. Mey. (Hypoxidaceae) corm ['African potato'] aqueous extract in mice and rats. J Ethnopharmacol 2006;103:126-34.

53. Oguntibeju OO, Meyer S, Aboua YG, Goboza M. Hypoxis hemerocallidea significantly reduced hyperglycaemia and hyperglycaemic-induced oxidative stress in the liver and kidney tissues of streptozotocin-induced diabetic male Wistar rats. Evid Based Complement Alternat Med 2016;2016:8934362.

54. Mabogo DE. The Ethnobotany of the Vhavenda. MSc Dissertation. Pretoria: University of Pretoria; 1990.

55. Anita BS, Okokon JE, Okon PA. Hypoglycemic activity of aqueous Persea americana Mill. Indan J Pharmacol 2005;37:25-6.

56. Reddy RM, Yanadaiah JP, Reddy KR, Kumar DL. Assessment of antidiabetic activity of ethanolic extract of Grewia flavescens. Juss leaves against alloxan induced diabetis in rats. J Glob Trends Pharm Sci 2013;4:1086-90.

57. Kannan M, Senthil KT, Rao MV. Antidiabetic and antioxidant properties of Waltheria indica L., an ethnomedicinal plant. Int J Pharm Res Health Sci 2016;4:1376-84.

58. Njagi JM, Piero MN, Ngeranwa JJN, Njagi ENM, Kibiti CM, Njue WM, et al. Assessment of antidiabetic potential of Ficus sycomorus on alloxan-induced diabetic mice. Int J Diabetes Res 2012;1:47-51.

59. Chauhan A. Role of Ficus carica in medicine: A review. Int J Interdiscip Res 2014;1:1-6.

60. Gupta R, Mathur M, Bajaj VK, Katariya P, Yadav S, Kamal R, et al. Evaluation of antidiabetic and antioxidant activity of moringa oleifera in experimental diabetes. J Diabetes 2012;4:164-71.

61. Basha SK, Kumari SV. In vitro antidiabetic activity of Psidium guajava leaves extracts. Asian Pac J Trop Dis 2012;2:98-100.

62. Bharti SK, Kumar A, Sharma NK, Prakash O, Jaiswal SK, Krishnan S, et al. Tocopherol from seeds of Cucurbita pepo against diabetes: Validation by in vivo experiments supported by computational docking. J Formos Med Assoc 2013;112:676-90.

63. Salwe KJ, Sachdev DO, Bahurupi Y, Kumarappan M. Evaluation of antidiabetic, hypolipedimic and antioxidant activity of hydroalcoholic extract of leaves and fruit peel of Punica granatum in male Wistar albino rats. J Nat Sci Biol Med 2015;6:56-62.

64. Mousinho NM, van Tonder JJ, Steenkamp V. In vitro anti-diabetic activity of Sclerocarya birrea and Ziziphus mucronata. Nat Prod Commun 2013;8:1279-84

65. Chauhan A, Sharma PK, Srivastava P, Kumar K, Dudhe D. Plants having potential antidiabetic activity: A review. Der Pharm Lett 2010;2:369-87.

66. Naim M, Amjad FM, Sultana S, Isalm SN, Hossain MA, Begum R, et al. A comparative study of antidiabetic activity of hexane-extract of lemon peel (Limon citrus) and glimepiride in alloxan-induced diabetic rats. Bangladesh Pharm J 2012;15:131-4.

67. Ziqubu-Page TT, Dangor CM, Makubalo LE, Chetty M. Determinants of traditional medicine use by diabetic patients in the Northern Kwa Zulu-Natal province. Curare 1999;22:49-61.

68. Mogale MA, Mkhombo HM, Lebelo SL, Shai LJ, Chauke MA, DeFreitas A. The effects of Clausena anisata (Wild) hook leaf extracts on selected diabetic related metabolizing enzymes. J Med Plant Res 2012;6:4200-7.

69. Dagne E, Bisrat D, Viljoen A, Van Wyk BE. Chemistry of aloe species. Curr Org Chem 2000;4:1055-78.

70. Schmelzer GH. Anthocleista grandiflora Gilg. In: Schmelzer GH, Gurib-Fakim A, editors. Plant Resources of Tropical Africa 11(1): Medicinal Plants 2. Wageningen: CTA; 2008. p. 101-2.

71. Gbolade AA. Inventory of antidiabetic plants in selected districts of Lagos state, Nigeria. J Ethnopharmacol 2009;121:135-9.

72. Muyenga TA, Musonda D, Chigunta M. Ethnobotanical survey of medical plants used in treatment of diabetes in chipulukusu compound, Ndola district, Zambia. J Prev Rehabil Med 2018;1:39-44.

73. Omoruyi BE, Bradley G, Afolayan AJ. Antioxidant and phytochemical properties of Carpobrotus edulis (L.) bolus leaf used for the management of common infections in HIV/AIDS patients in Eastern Cape province. BMC Complement Altern Med 2012;12:215.

74. Arendse ML. Medicinal Plant Use in the Dwarsrivier Valley, Stellenbosch. MSc Dissertation. Cape Town: University of the Western Cape; 2013

75. Mukundi M, Mwaniki N, Piero N, Murugi N, Daniel A. In vivo antidiabetic effects of aqueous leaf extracts of Rhoicissus tridentata in alloxan induced diabetic mice. J Dev Drugs 2015;4:2 .
76. Mootoosamy A, Fawzi Mahomoodally M. Ethnomedicinal application of native remedies used against diabetes and related complications in Mauritius. J Ethnopharmacol 2014;151:413-44.

77. Jayakumar G, Ajithabai MD, Sreedevi S, Viswanathan PK, Remeshkumar B. Ethnobotanical survey of the plants used in the treatment of diabetes. Indian J Tradit Knowl 2010;9:96-9.

78. Chaturvedi D, Shrivastava RR, Suhane N. Basketful benefit of Citrus limon. Int Res J Pharm 2016;7:1-4.

79. Moshi MJ, Mbwambo ZH. Experience of Tanzanian traditional healers in the management of non-insulin dependent diabetes mellitus. Pharm Biol 2002;40:552-60

80. Boaduo NK, Katerere D, Eloff JN, Naidoo V. Evaluation of six plant species used traditionally in the treatment and control of diabetes mellitus in South Africa using in vitro methods. Pharm Biol 2014;52:756-61.

81. Mahabir D, Gulliford MC. Use of medicinal plants for diabetes in Trinidad and Tobago. Rev Panam Salud Publica 1997;1:174-9.

82. Khan KY, Khan MA, Ahmad M. Ethno-medicinal species of genus Ficus L. used to treat diabetes in Pakistan. J Appl Pharm Sci 2011;1:209-11.

83. Oghenesuvwe E, Erhirhie I, Lodigwe EE, Ihekwereme CP. Ficus sycomorus L (Moraceae): A review on its phytopharmacology and toxicity profile. Discov Phytomed 2018;5:64-71.

84. Amjad MS. Ethnobotanical profiling and floristic diversity of Bana valley, Kotli (Azad Jammu and Kashmir), Pakistan. Asian Pac J Trop Biomed 2015;5:292-9.

85. Diallo A, Traore MS, Keita SM, Balde MA, Keita A, Camara M, et al. Management of diabetes in Guinean traditional medicine: An ethnobotanical investigation in the coastal lowlands. J Ethnopharmacol 2012;144:353-61

86. Arowosegbe S, Oyeyemi SD, Alo O. Investigation on the medicinal and nutritional potentials of some vegetables consumed in Ekiti State, Nigeria. Int Res J Nat Sci 2015;3:16-30.

87. Hutchings A, Scott AH, Lewis A, Cunningham AB. Zulu Medicinal Plants: An Inventory. Pietermaritzburg: University of Natal Press; 1996.

88. Mondal P, Bhuyan P, Das S, Kumar M, Borah S, Mahato S. Herbal medicines useful for the treatment of diabetes in North-East India: A review. Int J Pharm Biol Sci 2013;13:575-89.

89. Lans CA. Ethnomedicines used in Trinidad and Tobago for urinary problems and diabetes mellitus. J Ethnobiol Ethnomed 2006;2:45.

90. Al-Aboudi A, Afifi FU. Plants used for the treatment of diabetes in Jordan: A review of scientific evidence. Pharm Biol 2011;49:221-39.

91. Trojan-Rodrigues M, Alves TL, Soares GL, Ritter MR. Plants used as antidiabetics in popular medicine in rio grande do sul, Southern Brazil. J Ethnopharmacol 2012;139:155-63.

92. Aidi W, Marzouk WB. Research progress of Tunisian medicinal plants used for acute diabetes. J Acute Dis 2016;5:357-63.

93. Deutschländer MS, van de Venter M, Roux S, Louw J, Lall N. Hypoglycaemic activity of four plant extracts traditionally used in South Africa for diabetes. J Ethnopharmacol 2009;124:619-24.

94. Vidyasagar GM, Siddalinga MS. Medicinal plants used in the treatment of diabetes mellitus in Bellay district, Karnataka. Indian J Tradit Knowl 2013;12:747-51

95. Koffi N, Édouard KK, Kouassi K. Ethnobotanical study of plants used to treat diabetes, in traditional medicine, by abbey and Krobou people of Agboville (Côte-d'Ivoire). Am J Sci Res 2009;4:45-58.

96. Amuri B, Maseho M, Simbi L, Duez P, Byanga K. Ethnobotanical survey of herbs used in the management of diabetes mellitus in Southern Katanga area/DR congo. Pan Afr Med J 2018;30:218.

97. Amal MF, Masarrat MM. Ethnobotanical survey of plants used in the treatment of diabetes mellitus in Tabuk region, Saudi Arabia. Int J Curr Microbiol Appl Sci 2016;6:258-70.

98. Nasution BR, Aththorick TA, Rahayu S. Medicinal plants used in the treatment of diabetes in Karo ethnic, North Sumatra, Indonesia. Earth Environ Sci 2018;130:012038.

99. Laleye FO, Mensah S, Assogbadjo AE, Ahissou H. Diversity, knowledge, and use of plants in traditional treatment of diabetes in the Republic of Benin. Ethnobot Res Appl 2015;14:231-57.

100. Rahmatullah M, Azam MN, Khatun Z, Seraj S, Islam F, Rahman MA, et al. Medicinal plants used for treatment of diabetes by the marakh sect of the garo tribe living in Mymensingh district, Bangladesh. Afr J Tradit Complement Altern Med 2012;9:380-5.

101. Vidyasagar GM, Murthy SM. Medicinal plants used in the treatment of diabetes mellitus in Bellary district, Karnataka. Indian J Tradit Knowl 2014;12:747-51

102. Ong HO, Azliza MA. Medicinal plants for diabetes by the orang Asli 
in Selangor, Malaysia. Ethno Med 2015;9:77-84

103. Mustafa AA, Fawibe OO, Ajiboye AA, Agboola DA. Ethnobotanical survey of medicinal plants used in the treatment of diabetes in Irepodun Local government area of Osun state, Nigeria. Greener J Biol Sci 2012;5:59-68

104. Abubakar US, Abdullahi S, Victoria A, Shettima K, Usman SH, Ayuba MK. Medicinal plants used for the management of diabetes mellitus in Zaria, Kaduna state, Nigeria. J Pharm Pharmacogn Res 2017;5:156-64

105. Bussmann RW, Sharon D. Traditional medicinal plant use in Northern Peru: Tracking two thousand years of healing culture. J Ethnobiol
Ethnomed 2006;2:47.

106. Rasoanaivo P, Wright CW, Willcox ML, Gilbert B. Whole plant extracts versus single compounds for the treatment of malaria: Synergy and positive interactions. Malar J 2011;10 Suppl 1:S4

107. Firoz MV, Vishal GN, Sandeep K. Current trends and treatments in diabetic retinopathy. Asian J Pharm Clin Res 2019;12:27-33.

108. Mohanavamsi Y, Venkata RK, Subrahmanyeswari PN. Preliminary phytochemical investigation and evaluation of hypoglycemic activity of methanolic extract of MuntingiacalaburaL stem bark against normal and streptozotocin-induced diabetes. Asian J Pharm Clin Res 2019;12:137-42. 